\title{
UJI AKURASI KLASIFIKASI PENGGUNAAN LAHAN DENGAN MENGGUNAKAN METODE DEFUZZIFIKASI MAXIMUM LIKELIHOOD BERBASIS CITRAALOS AVNIR-2 Harvini Wulansari*
}

\begin{abstract}
Land use information plays an important role in spatial planning and monitoring development in order to optimize landuse and to minimize land conflict. Remote sensing technology can be used to derive land cover information for land use information. The aim of this research was to study the accuracy level and the efficiency of fuzzy logic for land use classification. Defuzzification method was implemented using maximum likelihood and its landuse map from classification result, using spectral data from ALOS AVNIR-2. This research used fuzzy logic approach with defuzzification method using maximum likelihood. Sample plots used for modelling were chosen using stratified random sampling method, and accuracy assessment was obtained using stratified random sampling method also. In overall, the research process worked well, although the standpoint of accuracy and thoroughness resulted in overall kappa index was less good or less feasible; however, the results were acceptable. For the 14 landuse classes, it resulted $57 \%$ of overall accuracy and kappa index of 0.53 . Time execution using maximum likelihood algorithm was approximately 10 seconds.
\end{abstract}

Key Words: landuse classification, ALOS AVNIR-2, fuzzy logic, maximum likelihood.

Intisari: Informasi data penggunaan lahan sangat berperan penting diantaranya untuk melakukan perencanaan maupun pengawasan perkembangan suatu wilayah, sehingga penggunaan lahannya dapat dimanfaatkan secara optimal dan tetap menjaga kelestariannya, serta meminimalkan terjadinya konflik terhadap lahan. Teknologi penginderaan jauh merupakan salah satu cara yang dapat dimanfaatkan untuk menurunkan data penutup lahan sebelum akhirnya diterjemahkan menjadi informasi penggunaan lahan. Tujuan dari penelitian ini yaitu untuk mengetahui seberapa akurat dan efisien metode pendekatan berbasis logika samar (fuzzy logic) dengan defuzzifikasi menggunakan algoritma maximum likelihood serta peta hasil klasifikasi penggunaan lahannya, yang melibatkan input data spektral dari Citra ALOS AVNIR-2. Metode yang digunakan dalam penelitian ini yaitu metode pendekatan berbasis logika samar (fuzzy logic) dengan defuzzifikasi menggunakan algoritma maximum likelihood. Penentuan sampel untuk training area dan uji akurasi menggunakan metode plot area sedangkan pengambilan sampel menggunakan metode stratified random sampling. Secara keseluruhan proses penelitian berhasil dengan baik, walaupun dari sudut pandang ketelitian menghasilkan overall accuracy dan indeks kappa yang kurang baik atau kurang layak, namun demikian hasilnya masih dapat diterima.Untuk 14 kelas penggunaan lahan (overall accuracy 57\%, nilai indeks kappa 0,53). Hasil pencatatan waktu untuk proses eksekusi menggunakan algoritma maximum likelihood sekitar 10 detik.

Kata kunci: klasifikasi penggunaan lahan, Citra ALOS AVNIR-2, logika samar, maximum likelihood.

\section{A. Pendahuluan}

Informasi data penggunaan lahan berperan penting diantaranya untuk melakukan perencanaan maupun pengawasan perkembangan suatu wilayah, sehingga penggunaan lahannya dapat dimanfaatkan secara optimal dengan tetap menjaga

* Staf Pengajar Sekolah Tinggi Pertanahan Nasional. Email: vinysari@yahoo.com kelestariannya, serta meminimalkan terjadinya konflik terhadap lahan. Menurut Lillesand et al. (2008) informasi penggunaan lahan tidak selalu dapat ditafsir langsung dari penutup lahannya oleh karena itu diperlukan informasi pelengkap untuk menentukan penggunaan lahan. Untuk menurunkan informasi penggunaan lahan dari citra penginderaan jauh diperlukan informasi pendukung di antaranya seperti data bentuk lahannya atau bisa 
dengan local knowledge mengenai wilayah tersebut.

Saat ini telah berkembang metode klasifikasi multispektral yang bisa dilakukan melalui berbagai pendekatan diantaranya menurut Jensen (2005) hard classification atau soft classifaction tergantung output yang dikehendaki, sedangkan berdasarkan distribusi datanya dapat menggunakan algoritma pendekatan parametrik misal maximum likelihood atau dengan pendekatan non parametrik misal jaringan syaraf tiruan (artificial neural network). Salah satu contoh algoritma yang menggunakan pendekatan parametrik yaitu algoritma maximum likelihood. Pendekatan parametrik mengasumsikan bahwa distribusi statistik kelas digambarkan dengan data yang terdistribusi normal atau bayesian. Sedangkan pendekatan non parametrik tidak mengharuskan distribusi statistik kelas digambarkan secara normal, salah satu contoh pendekatan non parametrik yaitu jaringan syaraf tiruan (artificial neural network).

Lillesand et al. (2008) menyatakan bahwa data penginderaan jauh merupakan hasil interaksi antara tenaga elektromagnetik dengan objek yang diindera yang direkam oleh sensor, dimana setiap objek mempunyai karakteristik tertentu dalam berinteraksi dengan setiap spektrum elektromagnetik. Danoedoro (2012) juga menyebutkan bahwa pada prinsipnya setiap benda memiliki struktur partikel yang berbeda, dimana perbedaan ini akan mempengaruhi pola respon elektromagnetiknya, yang dapat dijadikan landasan pembedaan objek.

Banyak penelitian mulai dikembangkan terkait dengan karakteristik pola respon spektral, di antaranya untuk mengektraksi data penutup lahan dari citra satelit. Pendekatan yang mulai berkembang diantaranya adalah klasif ikasi berbasis logika samar (fuzzy logic). Metode fuzzy sangat membantu saat proses pengambilan sampel, di mana tidak terjadi pemaksaan keanggotaan piksel untuk masuk ke dalam satu kelas saja (soft classification). Sampel yang diambil juga tidak harus piksel murni, dapat diambil pada mixed pixel. Seperti diketahui bahwa dari sudut pandang penginderaan jauh fenomena geograf is pada level skala menengah dan rendah bersifat fuzzy artinya tidak ada batas yang jelas (dalam arti tajam) antara fenomena-fenomenageograf is tersebut. Masalah mixed pixel terutama terjadi pada citra penginderaan jauh resolusi spasial menengah dan resolusi spasial rendah, dimana di dalam satu piksel citra dapat terdiri dari dua atau lebih jenis objek.

Metode pendekatan berbasis logika samar (fuzzy logic) secara operasional sistematik masih jarang digunakan di instansi-instansi yang bertugas membuat peta tematik seperti misalnya Badan Pertanahan Nasional/BPN RI. Selain itu penggunaan citra penginderaan jauh resolusi spasial menengah di instansi BPN RI sebagai masukan data penggunaan lahan juga jarang digunakan, data yang tersedia di instansi BPN RI berupa foto udara skala besar, citra dengan resolusi spasial tinggi seperti Citra Quickbird, sedangkan untuk citra dengan resolusi spasial menengah seperti Citra ALOS AVNIR-2 jarang digunakan, oleh karena itu perlu dikaji tingkat akurasi dari citra tersebut. Dari permasalahan tersebut maka peneliti melakukan sebuah penelitian untuk mengetahui seberapa akurat dan efisien pemetaan penggunaan lahan yang dihasilkan dengan menggunakan metode pendekatan berbasis logika samar (fuzzy logic) dengan defuzzifikasi menggunakan algoritma maximum likelihood. Penelitian ini dilakukan di sebagian wilayah Daerah Istimewa Yogyakarta dan sebagian wilayah Kabupaten Klaten, dengan luasan

${ }^{\mathrm{I}}$ Satelit ALOS (Advanced Land Observing Satellite) merupakan satelit sumber daya milik Jepang, yang terdiri dari tiga sensor yaitu Panchromatic Remote Sensing Instrument for Stereo Mapping (PRISM) dengan resolusi 2,5 meter, Advanced Visible and Near Infrared Radiometer type-2 (AVNIR-2) resolusi to meter dan Phased Array type L-band Synthetic Aperture Radar (PALSAR) resolusi Io meter dan Ioo meter. Walaupun saat ini sudah tidak beroperasi namun data yang dihasilkan masih banyak dimanfaatkan untuk berbagai macam kebutuhan informasi dan ekstraksi data. 
1506 x 1505 piksel atau sekitar 15 x $15 \mathrm{~km}^{2}$ (Citra ALOS AVNIR-2 resolusi spasial sekitar $10 \mathrm{~m}$ ). Citra ALOS AVNIR-2 yang digunakan yaitu citra yang direkam tanggal 20 Juni tahun 2009 level ${ }_{132} \mathrm{G}$, dapat dilihat pada gambar 1.

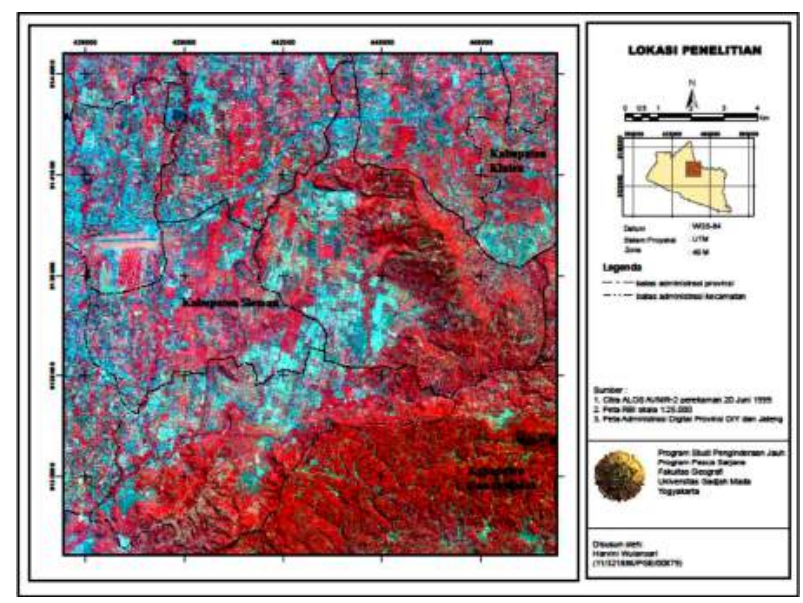

Gambar I. Lokasi Penelitian

\section{B. Klasifikasi Multispektral}

Danoedoro (2012) menyebutkan bahwa klasifikasi multispektral merupakan suatu metodeyang dirancang untuk menurunkan informasi tematik dengan cara mengelompokkan fenomena berdasarkan kriteria tertentu, yang pada dasarnya diasumsikan bahwa tiap objek dapat dibedakan dengan objek yang lain berdasarkan nilai spektralnya dimana tiap-tiap objek tersebut cenderung memberikan pola respon spektral yang spesifik.

Algoritma klasifikasi multispektral berdasarkan pada asumsi distribusi datanya menurut Schowengerdts (1983) dapat dibedakan menjadi parametrik dan non parametrik. Algoritma parametrik mengasumsikan bahwa distribusi statistik kelas digambarkan dengan distribusi normal dan mengestimasikan parameter yang didistribusikan dengan vektor rerata dan matriks kovarian, sedangkan algoritma non parametrik tidak mengasumsikan distribusi kelas.

Algoritma maximum likelihood merupakan salah satu contoh pendekatan parametrik. Danoedoro (2012) menyebutkan bahwa Algoritma maximum likelihood merupakan algoritma yang secara statistik mapan, dengan asumsi bahwa objek homogen selalu menampilkan histogram yang terdistribusi normal atau bayesian.

Menurut Shresta (1991 dalam Danoedoro 2012) algoritma maximum likelihood dikelaskan sebagai objek tertentu berdasarkan bentuk ukuran dan orientasi sampel pada feature space yang berbentuk elipsoida, dapat dilihat gambaran algoritma maximum likelihood pada gambar 2. Informasi nilai statistik yang dibutuhkan pada klasifikasi menggunakan algoritma maximum likelihood yaitu nilai rerata (mean), simpangan baku serta variansi dan kovariansinya.
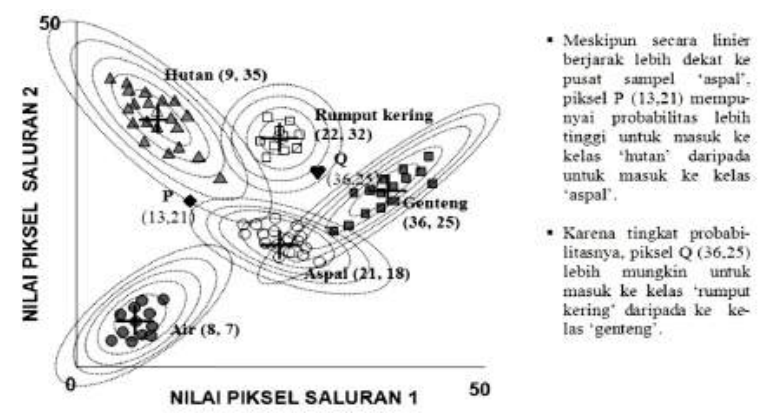

Gambar 2. Fungsi kerapatan yang digambarkan dengan algoritma maximum likelihood modifikasi dari Lillesand et al, (2008, dalam Danoedoro, 2012)

\section{Klasifikasi dengan Logika Fuzzy}

Menurut Kusumadewi (2010), logika fuzzy merupakan salah satu komponen pembentuk soft computing, dimana peranan derajat keanggotaan atau membership function sebagai penentu keberadaan elemen dalam suatu himpunan sangat penting. Himpunan fuzzy nilai keanggotaan terletak pada interval o sampai dengan 1. Novamizanti et.al. (2010) dalam tulisannya menjelaskan bahwa sebuah sistem fuzzy memiliki struktur proses sebagai berikut: 1). Fuzzification (fuzzifikasi), yaitu proses memetakan crisp input ke dalam himpunan fuzzy. Hasil dari proses ini berupa fuzzy input dalam bentuk rule fuzzy 2). Evaluation Rule, yaitu proses melakukan penalaran terhadap fuzzy input yang dihasilkan oleh proses fuzzification berdasarkan 
aturan fuzzy yang telah dibuat. Proses ini menghasilkan fuzzy output 3). Defuzzification (defuzzifikasi), yaitu proses mengubah fuzzy output menjadi crisp value.

Jensen (2005) menggambarkan bagaimana logika fuzzy diterapkan untuk proses klasifikasi nilai piksel terhadap jenis penutup/penggunaan lahan dapat dilihat pada gambar 3. Dari gambar tersebut dapat dilihat perbandingan antara klasifikasi tegas dan klasifikasi berbasis logika fuzzy.

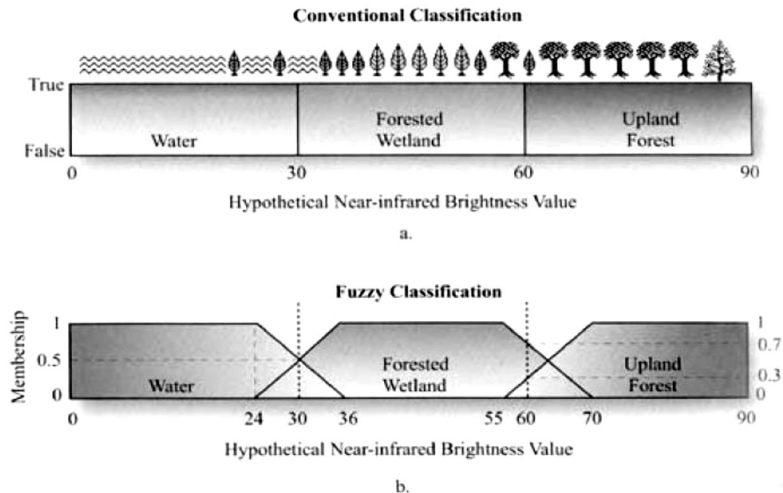

Gambar 3. Perbandingan antara kalsifikasi tegas dan klasifikasi berbasis logika fuzzy (Jensen, 2005)

\section{Tahapan Lapangan}

Tahapan penelitian yang dilakukan meliputi Tahap Pra Lapangan, Tahap Kegiatan Lapangan, Tahap Pemrosesan dan Tahap Pasca Lapangan (Uji Akurasi). Tahapan-tahapan tersebut dapat dilihat pada gambar 4 .

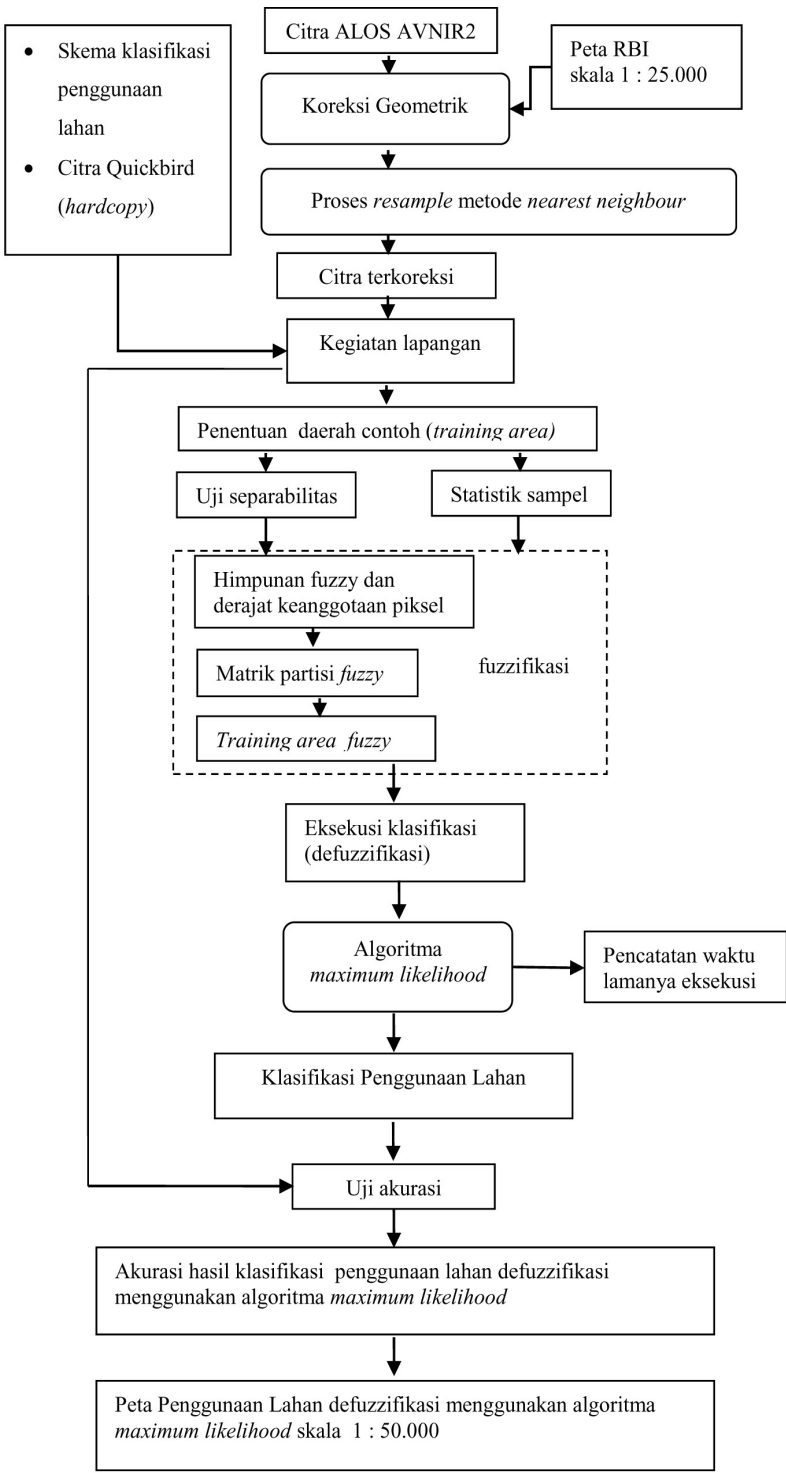

Gambar 4. Diagram alir penelitian

\section{Tahap Pra Lapangan}

\section{a. Koreksi Geometrik}

Sebelum citra digital diolah terlebih dahulu dilakukan koreksi citra. Tahapan ini dilakukan karena saat sensor melakukan perekaman data di permukaan bumi terdapat beberapa faktor yang mempengaruhi kualitas citra baik dari wahananya sendiri atau di luar wahana. Koreksi geometrik dilakukan untuk melakukan perbaikan distorsi geometrik citra terhadap kondisi sebenarnya di lapangan. Koreksi geometrik yang dilakukan yaitu dengan transformasi berdasarkan ground control point (GCP) dengan melakukan rektifikasi citra ke peta, prinsip rektifikasi citra ke peta bahwa peta 
yang digunakan sebagai acuan memiliki sistem proyeksi dan koordinat yang lebih dapat dipercaya atau lebih dianggap benar daripada citra. Peta yang digunakan acuan untuk koreksi geometrik adalah peta RBI skala 1: 25.0oo. Proses koreksi geometrik dilakukan pada software ENVI dengan cara registrasi image to map. Peta RBI skala 1: 25.00o yang digunakan acuan sudah dilakukan proses georeference terlebih dahulu.

Interpolasi spasial yang digunakan menggunakan fungsi persamaan polinomial orde dua sebanyak 10 titik GCP yang tersebar merata di wilayah penelitian, dengan menggunakan proyeksi Universal Transverse Mercator (UTM) datum WGS - 84 zone 49 M. Penentuan 10 titik GCP tersebut sudah mencukupi karena syarat untuk polinomial orde dua adalah sebanyak 6 titik dan juga setelah di-overlay dengan peta RBI skala 1: 25.00o sudah sama antara perpotongan jalan dan percabangan sungainya. Titik-titik kontrol diambil secara merata di wilayah penelitian yang dapat dilihat pada gambar 5. Titik-titik kontrol diambil pada perpotongan jalan, jembatan, percabangan aliran sungai dan bangunan yang bersifat permanen/tetap.

Koreksi geometrik menghasilkan nilai Root Mean Square Error (RMSE) o,45. Hasil tersebut sudah memenuhi syarat untuk citra tunggal minimal RMSE yang diperbolehkan kurang dari 1. Pada saat proses koreksi geometrik dilakukan pula proses resample nilai piksel citra dengan metode nearest neighbour yaitu menempatkan nilai piksel tetangga terdekat untuk mengisi piksel yang digeser agar nilai piksel hasil koreksi tidak jauh berbeda dengan nilai piksel citra sebelum dilakukan proses koreksi geometrik.

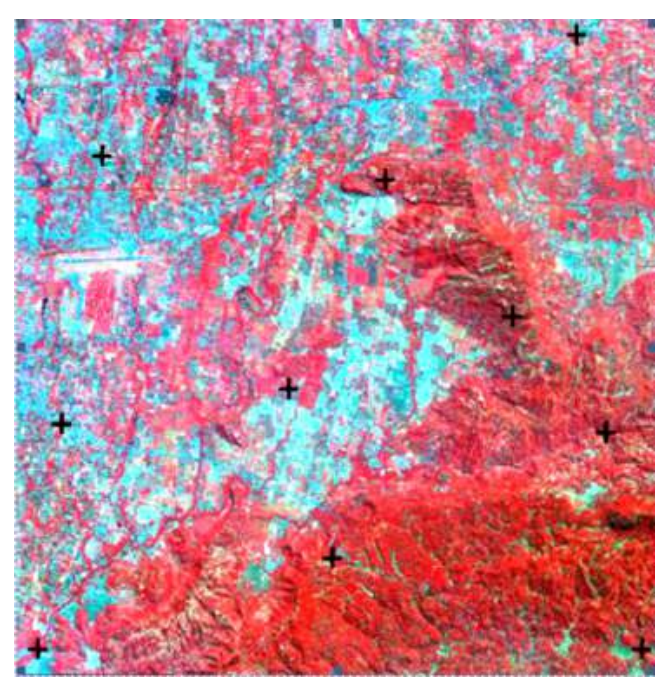

Gambar 5. Lokasi Titik-titik GCP

\section{a. Penentuan Skema Klasifikasi Penggunaan Lahan}

Citra ALOS AVNIR-2 yang memiliki resolusi spasial 10 meter menurut Doyle (1984 dalam Sutanto, 2010) tingkat akurasi interpretasi atau akurasi klasifikasi sesuai dengan rumus a rule of thumb yaitu sama dengan tingkat akurasi pada skala peta 1 : 100.ooo. Oleh karena itu, dalam penelitian ini dipilih skema klasifikasi penggunaan lahan untuk skala 1 : 50.0ooyang dibuatoleh BPN RI yang dianggap masih mendekati skala 1:10o.ooo. Dalam penentuan penggunaan lahannya dilakukan modifikasi yang berbasis pada penutup lahannya dilihat pada pada tabel 1 .

Tabel 1. Skema klasifikasi penggunaan lahan yang digunakan dalam penelitian (modifikasi atas klasifikasi penggunaan lahan BPN RI)

\begin{tabular}{|c|c|c|c|}
\hline No. & Identifikasi penutup lahan & $\begin{array}{l}\text { Kelas Penggunaan } \\
\text { Lahan }\end{array}$ & Singkatan \\
\hline \multirow{3}{*}{$\begin{array}{l}1 \\
2 \\
3\end{array}$} & \multirow{3}{*}{$\begin{array}{l}\text { Vegetasi berkayu kerapatan rendah } \\
\text { Vegetasi berkayu kerapatan rendah } \\
\text { Atap genteng }\end{array}$} & tegalan/ladang & \multirow{3}{*}{$\begin{array}{l}\mathrm{tg} \\
\mathrm{sm} \\
\mathrm{pm}\end{array}$} \\
\hline & & Semak & \\
\hline & & Permukiman & \\
\hline \multirow{2}{*}{$\begin{array}{l}4 \\
5 \\
\end{array}$} & \multirow{2}{*}{$\begin{array}{l}\text { Aspal } \\
\text { Vegetasi tak berkayu kerapatan sedang }\end{array}$} & tanah jasa & \\
\hline & & tempat olahraga & \\
\hline \multirow{2}{*}{$\begin{array}{l}6 \\
7\end{array}$} & \multirow{2}{*}{$\begin{array}{l}\text { Vegetasi tak berkayu kerapatan tinggi } \\
\text { Vegetasi berkayu kerapatan tinggi }\end{array}$} & sawah irigasi & \multirow{2}{*}{$\begin{array}{l}\mathrm{si} \\
\mathrm{kc}\end{array}$} \\
\hline & & kebun campuran & \\
\hline \multirow{2}{*}{$\begin{array}{l}8 \\
9\end{array}$} & \multirow{2}{*}{$\begin{array}{l}\text { Atap genteng } \\
\text { Atap asbes }\end{array}$} & Peternakan & \multirow{3}{*}{$\begin{array}{l}\mathrm{pt} \\
\mathrm{ti} \\
\mathrm{at}\end{array}$} \\
\hline & & tanah industri & \\
\hline 10 & Air dangkal & $\begin{array}{l}\text { pemanfaatan berbasis } \\
\text { air tergenang }\end{array}$ & \\
\hline 11 & Air dangkal & $\begin{array}{l}\text { pemanfaatan berbasis } \\
\text { sungai }\end{array}$ & sg \\
\hline \multirow{2}{*}{$\begin{array}{l}12 \\
13 \\
\end{array}$} & \multirow{2}{*}{$\begin{array}{l}\text { Tanah terbuka dan kering dan } \\
\text { vegetasi berkayu kerapatan rendah } \\
\text { Vegetasi berkayu kerapatan tinggi }\end{array}$} & Sawah non irigasi & \multirow{2}{*}{$\begin{array}{l}\text { sn } \\
\text { hs }\end{array}$} \\
\hline & & Hutan sejenis & \\
\hline 14 & $\begin{array}{l}\text { Tanah terbuka dan kering dan lahan } \\
\text { terbangun }\end{array}$ & Penggunaan lain & $\mathrm{pl}$ \\
\hline
\end{tabular}

Sumber : BPN RI, 2012 dengan modifikasi 


\section{Tahap Kegiatan Lapangan}

Kegiatan lapangan meliputi kerja lapangan ditujukan untuk memperoleh data lapangan yang digunakan sebagai penentuan daerah contoh atau training area sekaligus mencari informasi apakah terjadi adanya perubahan penggunaan lahan antara citra yang digunakan dengan kondisi saat ini serta cek lapangan untuk sampel uji akurasi.

Citra yang digunakan dalam penelitian ini yaitu Citra ALOS AVNIR-2 yang direkam pada tahun 2009, sedangkan penelitian dilakukan pada tahun 2013 sehingga dimungkinkan telah terjadi perubahan penggunaan lahan di lapangan, sehingga perlu dilakukan kerja lapangan untuk melakukan wawancara dengan penduduk sekitar.

Pendekatan yang digunakan dalam survei dan pemetaan penggunaan lahan yaitu photo key approach yang merupakan pendekatan yang bersifat fotomorfik dimana kenampakan pada foto menjadi kunci pengenalan objek, dengan menggunakan citra resolusi spasial tinggi berupa Citra Quickbird. Hal ini dilakukan untuk membantu mencocokkan sampel, yang sebelumnya sudah ditentukan sebelum berangkat ke lapangan dengan kenyataanyang sebenarnya dilapangan sebagai contoh sebelum ke lapangan hasil interpretasi bahwa objek tersebut adalah sawah irigasi setelah di lapangan apakah benar objek yang dimaksud memang sawah irigasi atau berupa tegalan/ladang, seperti yang dapat dilihat pada gambar 6 .

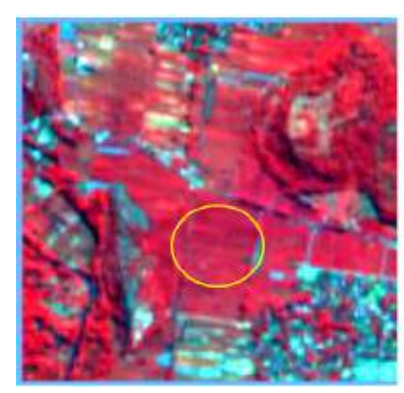

(a). Citra ALOS AVNIR-2

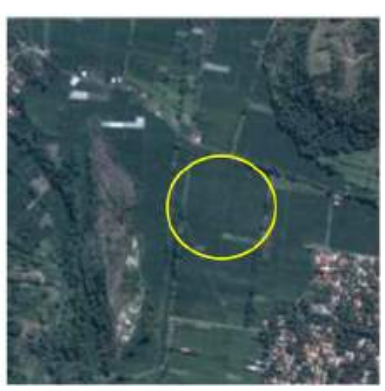

(b). Citra Quickbird
Gambar 6. Pendekatan photo key approach yang menunjukkan obyek sawah irigasi pada (a). Citra ALOS AVNIR-2 dan (b). Citra Quickbird
Penentuan titik-titik sampel yang digunakan untuk daerah contoh menggunakan pendekatan stratified random sampling, titik sampel ditentukan secara acak pada setiap strata dan diusahakan terdistribusi secara merata di seluruh daerah penelitian. Sebagaimana dikemukakan oleh Lillesand et.al. (2008) untuk dapat menghitung vektor mean dan matriks kovarian (seperti metode maximum likelihood) dibutuhkan minimum 1on to 1oon piksel dimana $n$ merupakan jumlah band, yang berarti jika dalam penelitian ini menggunakan Citra ALOS yang memiliki 4 band maka minimum 40-400 piksel diambil untuk tiap kategori dan diambil pada beberapa lokasi yang berbeda. Dalam penelitian ini plot area sampel daerah contoh dan sampel uji minimal yaitu 100 piksel, jika Citra ALOS AVNIR dengan resolusi spasial $10 \mathrm{~m}$ maka berkisar 10.000 $\mathrm{m}^{2}$ atau 1 hektar untuk satu kelas penggunaan lahan, yang diambil pada tempat yang berbeda.

Sesuai dengan acuan skema penggunaan lahan yang digunakan dan dengan melihat keadaan di lapangan, maka dalam penelitian ini ada 14 kelas penggunaan lahan yang digunakan yaitu tegalan/ ladang, semak, permukiman, tanah jasa, tempat olahraga, sawah irigasi, kebun campuran, peternakan, industri, pemanfaatan berbasis air tergenang, pemanfaatan berbasis sungai, sawah non irigasi, hutan sejenis dan penggunaan lain.

Penggunaan lahan pemanfaatan berbasis air tergenangyang dimaksudkan adalah seperti kolam ikan atau empang, sedangkan penggunaan tanah jasa seperti jalan aspal dan bandar udara (bandara). Penggunaan lahan yang dimasukkan dalam kelas penggunaan lain yaitu bangunan candi dan lahan kosong.

\section{Tahap Pemrosesan}

\section{a. Hasil Uji Separabilitas}

Uji separabilitas objek dihitung dengan menggunakan algoritma transformed divergence (TD). Uji separabilitas dilakukan untuk mengetahui tingkat keterpisahan nilai spektral antar objek. 
Penelitian ini menggunakan software ENVI untuk menghitung tingkat keterpisahan objeknya, dimana untuk nilai maksimumnya adalah 2 atau setara dengan nilai 2000 apabila menggunakan software Idrisi Selva, yang berarti bahwa kelas yang diuji benar-benar terpisah secara baik atau maksimal sehingga dapat dibedakan antara kelas satu dengan yang lain secara baik. Nilai separabilitas dibawah 1,7 dianggap kurang baik yang berarti bahwa ada mixed piksel/piksel campuran didalamnya. Dalam penelitian ini ditetapkan ambang nilai minimum 1, sebagai batas bahwa kelas tersebut masih bisa dibedakan, apabila kurang dari 1 maka harus dijadikan satu kelas. Indeks separabilitas 14 kelas penggunaan lahan dapat dilihat pada tabel 2.

Tabel 2. Indeks separabilitas untuk 14 kelas penggunaan lahan

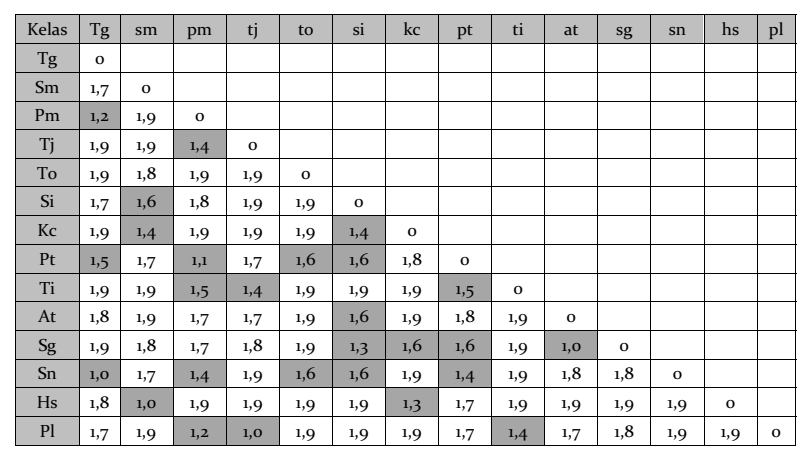

Sumber: Pengolahan penelitian, 2013

Keterangan: = adanya mixed piksel/piksel campuran

Dari tabel 2 dapat dilihat contoh bahwa kelas penggunaan lahan tegalan/ladang (tg) memiliki tingkat keterpisahan yang kurang baik terhadap kelas penggunaan lahan permukiman ( $\mathrm{pm}$ ), peternakan (pt) dan sawah non irigasi (sn), kemudian kelas penggunaan lahan semakyang juga memiliki keterpisahan yang kurang baik terhadap sawah irigasi (si), kebun campuran (kc) dan hutan sejenis.

\section{b. Hasil Penentuan Himpunan \\ Keanggotaan Kelas Penggunaan Lahan}

Himpunan nilai derajat keanggotaan piksel untuk masuk dalam satu kelas penggunaan lahan tertentu ditentukan dari parameter statistik hasil perhitungan statistik sampel. Nilai mean (rerata) dan standar deviasi merupakan parameter statistik utama dalam penentuan himpunan keanggotaan piksel, dimana nilai mean (rerata) menunjukkan nilai tengah kurva keanggotaan piksel terhadap suatu kelas penggunaan lahan, sedangkan standar deviasi sebagai acuan lebar kurva.

Hasil perhitungan statistik untuk 14 kelas penggunaan lahan dapat dilihat pada tabel 3 sampai dengan tabel 6.

Tabel 3. Hasil perhitungan statistik band 1 untuk 14 kelas penggunaan lahan

\begin{tabular}{|c|c|c|c|c|c|c|c|}
\hline \multirow[b]{2}{*}{ No } & \multirow[b]{2}{*}{$\begin{array}{c}\text { Kelas } \\
\text { LU }\end{array}$} & \multicolumn{6}{|c|}{ Band 1} \\
\hline & & Minimum & Maximum & Mean & $\begin{array}{c}\text { Stand. } \\
\text { Deviatio } \\
\text { n }\end{array}$ & $\mathrm{b}$ & c \\
\hline 1 & $\operatorname{tg}$ & 81 & 105 & 88,993 & 5,522 & 83,471 & 94,515 \\
\hline 2 & $\mathrm{sm}$ & 73 & 87 & 79,358 & 3,239 & 76,119 & 82,597 \\
\hline 3 & $\mathrm{pm}$ & 77 & 128 & 96,116 & 8,310 & 87,806 & 104,426 \\
\hline 4 & tj & 91 & 179 & 101,85 & 14,175 & 87,675 & 116,025 \\
\hline 5 & To & 85 & 154 & 92,687 & 11,399 & 81,288 & 104,086 \\
\hline 6 & $\mathrm{Si}$ & 81 & 102 & 84,712 & 2,923 & 81,789 & 87,635 \\
\hline 7 & Kc & $7^{6}$ & 83 & 79,206 & 1,407 & 77,799 & 80,613 \\
\hline 8 & $\mathrm{Pt}$ & 81 & 191 & 103,189 & 24,704 & 78,485 & 127,893 \\
\hline 9 & $\mathrm{Ti}$ & 86 & 234 & 144,800 & 44,309 & 100,491 & 189,109 \\
\hline 10 & At & 78 & 95 & 82,972 & 2,548 & 80,424 & 85,52 \\
\hline 11 & $\mathrm{Sg}$ & 80 & 94 & 85,588 & 2,591 & 82,997 & 88,179 \\
\hline 12 & Sn & 79 & 101 & 90,216 & 4,131 & 86,085 & 94,347 \\
\hline 13 & $\mathrm{Hs}$ & 71 & 84 & 75,523 & 1,936 & 73,587 & 77,459 \\
\hline 14 & $\mathrm{Pl}$ & 81 & 113 & 96,043 & 6,303 & 89,74 & 102,346 \\
\hline
\end{tabular}

Sumber : Pengolahan penelitian, 2013

Tabel 4. Hasil perhitungan statistik band 2 untuk 14 kelas penggunaan lahan

\begin{tabular}{|c|c|c|c|c|c|c|c|}
\hline \multirow{2}{*}{ No } & \multirow{2}{*}{$\begin{array}{c}\text { Kelas } \\
\text { LU }\end{array}$} & \multicolumn{7}{|c|}{ Band } \\
\cline { 3 - 8 } & Minimum & Maximum & Mean & $\begin{array}{c}\text { Stand. } \\
\text { Deviation }\end{array}$ & $\mathrm{b}$ & $\mathrm{c}$ \\
\hline 1 & $\mathrm{Tg}$ & 64 & 95 & 72,434 & 6,812 & 65,622 & 79,246 \\
\hline 2 & $\mathrm{Sm}$ & 48 & 76 & 61,358 & 5,626 & 55,732 & 66,984 \\
\hline 3 & $\mathrm{Pm}$ & 52 & 111 & 76,78 & 10,319 & 66,461 & 87,099 \\
\hline 4 & $\mathrm{Tj}$ & 64 & 176 & 77,517 & 17,862 & 59,655 & 95,379 \\
\hline 5 & $\mathrm{To}$ & 69 & 107 & 77,747 & 6,340 & 71,407 & 84,087 \\
\hline 6 & $\mathrm{Si}$ & 57 & 86 & 63,266 & 4,985 & 58,281 & 68,251 \\
\hline 7 & $\mathrm{Kc}$ & 49 & 63 & 55,528 & 2,513 & 53,015 & 58,041 \\
\hline 8 & $\mathrm{Pt}$ & 58 & 205 & 88,299 & 32,367 & 55,932 & 120,666 \\
\hline 9 & $\mathrm{Ti}$ & 59 & 253 & 133,92 & 52,459 & 81,462 & 186,38 \\
\hline 10 & $\mathrm{At}$ & 50 & 77 & 59,472 & 4,809 & 54,663 & 64,281 \\
\hline 11 & $\mathrm{Sg}$ & 49 & 77 & 63,438 & 5,122 & 58,316 & 68,56 \\
\hline 12 & $\mathrm{Sn}$ & 62 & 99 & 77,898 & 6,856 & 71,042 & 84,754 \\
\hline 13 & $\mathrm{Hs}$ & 46 & 68 & 52,594 & 3,275 & 49,319 & 55,869 \\
\hline 14 & $\mathrm{Pl}$ & 50 & 102 & 75,596 & 8,806 & 66,79 & 84,402 \\
\hline
\end{tabular}

Sumber : Pengolahan penelitian, 2013 
Tabel 5. Hasil perhitungan statistik band 3 untuk 14 kelas penggunaan lahan

\begin{tabular}{|c|c|c|c|c|c|c|c|}
\hline \multirow{2}{*}{ No } & \multirow{2}{*}{$\begin{array}{c}\text { Kelas } \\
\text { LU }\end{array}$} & \multicolumn{7}{|c|}{ Band 3 } \\
\cline { 3 - 8 } & & Minimum & Maximum & Mean & $\begin{array}{c}\text { Stand. } \\
\text { Deviation }\end{array}$ & b & c \\
\hline 1 & tg & 46 & 101 & 62,307 & 11,658 & 50,649 & 73,965 \\
\hline 2 & sm & 30 & 56 & 40,140 & 5,264 & 34,876 & 45,404 \\
\hline 3 & pm & 38 & 127 & 72,386 & 15,707 & 56,679 & 88,093 \\
\hline 4 & tj & 50 & 165 & 65,915 & 19,334 & 46,581 & 85,249 \\
\hline 5 & to & 41 & 110 & 59,590 & 12,579 & 47,011 & 72,169 \\
\hline 6 & si & 36 & 69 & 43,24 & 6,567 & 36,673 & 49,807 \\
\hline 7 & $\mathrm{kc}$ & 30 & 44 & 34,853 & 2,443 & 32,41 & 37,296 \\
\hline 8 & $\mathrm{pt}$ & 36 & 197 & 74,39 & 35,209 & 39,181 & 109,599 \\
\hline 9 & $\mathrm{ti}$ & 45 & 255 & 129,023 & 54,884 & 74,139 & 183,907 \\
\hline 10 & $\mathrm{at}$ & 32 & 60 & 41,341 & 5,251 & 36,09 & 46,592 \\
\hline 11 & $\mathrm{sg}$ & 31 & 62 & 42,823 & 4,836 & 37,987 & 47,659 \\
\hline 12 & $\mathrm{sn}$ & 45 & 111 & 70,153 & 13,998 & 56,155 & 84,151 \\
\hline 13 & $\mathrm{hs}$ & 28 & 58 & 33,738 & 4,249 & 29,489 & 37,987 \\
\hline 14 & $\mathrm{pl}$ & 36 & 99 & 66,579 & 10,762 & 55,817 & 77,341 \\
\hline
\end{tabular}

Sumber : Pengolahan penelitian, 2013

Tabel 6. Hasil perhitungan statistik band 4 untuk 14 kelas penggunaan lahan

\begin{tabular}{|c|c|c|c|c|c|c|c|}
\hline \multirow{2}{*}{ No } & \multirow{2}{*}{$\begin{array}{c}\text { Kelas } \\
\text { LU }\end{array}$} & \multicolumn{7}{|c|}{ Band 4 } \\
\cline { 3 - 8 } & & Minimum & Maximum & Mean & $\begin{array}{c}\text { Stand. } \\
\text { Deviation }\end{array}$ & b & c \\
\hline 1 & tg & 40 & 87 & 60,592 & 9,943 & 50,649 & 70,535 \\
\hline 2 & sm & 59 & 104 & 85,126 & 8,416 & 76,71 & 93,542 \\
\hline 3 & $\mathrm{pm}$ & 36 & 85 & 52,166 & 9,498 & 42,668 & 61,664 \\
\hline 4 & $\mathrm{tj}$ & 24 & 68 & 34,021 & 9,306 & 24,715 & 43,327 \\
\hline 5 & $\mathrm{to}$ & 62 & 112 & 94,645 & 10,564 & 84,081 & 105,209 \\
\hline 6 & $\mathrm{si}$ & 41 & 85 & 73,026 & 8,361 & 64,665 & 81,387 \\
\hline 7 & $\mathrm{kc}$ & 51 & 101 & 74,362 & 9,506 & 64,856 & 83,868 \\
\hline 8 & $\mathrm{pt}$ & 44 & 99 & 68,89 & 13,281 & 55,609 & 82,171 \\
\hline 9 & $\mathrm{ti}$ & 33 & 105 & 58,023 & 17,464 & 40,559 & 75,487 \\
\hline 10 & at & 16 & 84 & 34,093 & 15,827 & 18,266 & 49,92 \\
\hline 11 & $\mathrm{sg}$ & 12 & 108 & 43,624 & 19,558 & 24,066 & 63,182 \\
\hline 12 & $\mathrm{sn}$ & 35 & 96 & 66,114 & 12,853 & 53,261 & 78,967 \\
\hline 13 & $\mathrm{hs}$ & 55 & 92 & 76,082 & 7,282 & 68,8 & 83,364 \\
\hline 14 & $\mathrm{pl}$ & 18 & 70 & 36,421 & 7,000 & 29,421 & 43,421 \\
\hline
\end{tabular}

Sumber : Pengolahan penelitian, 2013

Cara penentuan derajat keanggotaan karena bersifat keahlian penganalisis maka sebetulnya harus dilakukan oleh orang yang benar-benar ahli bukan pemula. Penelitian ini dalam pertimbangan penentuan himpunan dan derajat keanggotaan selain pengetahuan lokal (local knowledge) terhadap wilayah penelitian juga dibantu dengan diagram pencar atau feature space, membuat kurva kosinus secara manual dengan menggunakan software microsoft excel dan juga dengan bantuan citra fuzzy kelas penggunaan lahannya.

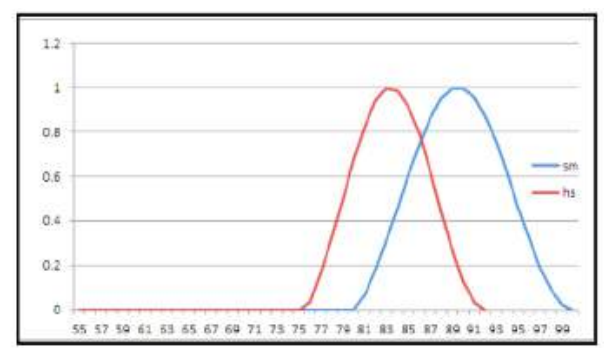

Gambar 7. Kurva kosinus kelas semak (sm) dengan hutan sejenis (hs)

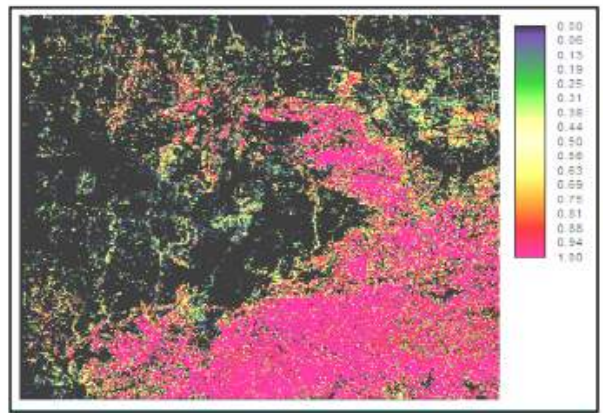

Gambar 8. Contoh citra kelas fuzzy untuk kelas hutan sejenis

Contoh grafik dapat dilihat pada gambar 7 , sedangkan contoh citra fuzzy dapat dilihat pada gambar 8. Pada gambar 8, contoh citra kelas fuzzy menggambarkan bahwa semakin mendekati nilai 1 (warna merah) makin masuk kedalam kelas yang bersangkutan dalam hal ini yaitu hutan sejenis, sebaliknya semakin mendekati nilai o (biru tua) maka semakin tidak masuk kelas hutan sejenis.

Setelah penentuan himpunan dan derajat keanggotaan dibuat, maka kemudian menyusun matrik partisi fuzzy. Matrik partisi fuzzy ditentukan atas dasar nilai derajat keanggotaan setiap sampel. Matrik partizi fuzzy berupa data tabularyang terdiri dari baris dan kolom, dimana tiap baris berisikan informasi ID kelas penggunaan lahan pada training site yang telah dibuat sementara kolom berisikan kelas penggunaan lahannya. Tabel ini diisi sesuai dengan derajat keanggotaan yang telah ditentukan, dapat dilihat pada tabel 7 . 
Tabel 7. Matriks partisi untuk 14 kelas penggunaan lahan

\begin{tabular}{|c|c|c|c|c|c|c|c|c|c|c|c|c|c|c|}
\hline ID & $\operatorname{tg}$ & $\mathrm{sm}$ & $\mathrm{Pm}$ & tj & to & $\mathrm{Si}$ & $\mathrm{Kc}$ & $\mathrm{pt}$ & $\mathrm{Ti}$ & at & Sg & sn & hs & $\mathrm{pl}$ \\
\hline $\operatorname{tg}$ & 0,65 & o & 0,05 & $\circ$ & o & o & o & 0,2 & o & o & o & 0,1 & o & o \\
\hline sm & o & 0,6 & o & o & o & o & 0,05 & o & o & o & o & o & 0,35 & o \\
\hline $\mathrm{pm}$ & o & 。 & 0,7 & o & o & o & o & 0,2 & o & o & o & o & o & 0,1 \\
\hline ti & o & $\circ$ & 0,04 & 0,72 & $\circ$ & o & o & $\mathrm{o}$ & o & o & o & o & $\circ$ & 0,26 \\
\hline to & o & o & o & o & 0,6 & o & o & 0,4 & o & o & o & o & o & o \\
\hline si & o & o & o & o & o & 0,89 & 0,11 & o & o & o & o & o & o & o \\
\hline $\mathrm{kc}$ & o & o & o & o & $\circ$ & 0,05 & 0,95 & o & $\circ$ & o & o & o & o & o \\
\hline $\mathrm{pt}$ & o & o & 0,15 & o & o & $\mathrm{o}$ & o & 0,8 & 0,05 & o & o & o & $\mathrm{o}$ & o \\
\hline $\mathrm{ti}$ & $\mathrm{o}$ & $\mathrm{o}$ & 0,1 & 0,15 & $\circ$ & $\mathrm{o}$ & o & 0,13 & 0,62 & o & o & $\mathrm{o}$ & o & o \\
\hline at & o & o & o & $\mathrm{o}$ & $\circ$ & $\mathrm{o}$ & o & $\mathrm{o}$ & o & 0,75 & 0,25 & o & o & o \\
\hline $\mathrm{sg}$ & o & o & o & o & o & o & o & o & o & 0,16 & 0,84 & o & o & o \\
\hline sn & 0,1 & o & 0,18 & o & o & o & o & 0,1 & o & o & o & 0,62 & o & o \\
\hline hs & o & 0,18 & o & o & o & o & 0,3 & o & o & o & o & o & 0,52 & o \\
\hline $\mathrm{pl}$ & o & o & 0,2 & 0,15 & o & $\mathrm{o}$ & o & $\mathrm{o}$ & o & $\circ$ & o & o & o & 0,65 \\
\hline
\end{tabular}

Sumber: Pengolahan penelitian, 2013

Dalam mengisi baris-baris tabel matrik partisi memperhatikan hubungan tingkat keterpisahan kelasyang dapat dilihat pada tabel 2. Sebagai contoh kelas penggunaan lahan tegalan/ladang (tg) memiliki keterpisahan yang kurang baik terhadap kelas penggunaan lahan permukiman (pm), peternakan (pt) dan sawah non irigasi (sn), maka baris-baristersebutyang nantinya diisikan bobotatau atau nilai derajat keanggotaan, besarnya nilai bobot dalam penelitian ini berdasarkan pertimbangan local knowledge wilayah kajian juga dibantu dengan diagram pencar (feature space), grafik kosinus dan citra kelas fuzzy-nya. Caranya yaitu dengan bantuan citra kelas fuzzy dan local knowledge wilayah kajian, diambil suatu luasan kajian yang mencakup kelas penggunaan lahan yang akan ditentukan nilai derajat keanggotaannya, maka yang lebih dominan pada luasan tersebut yang diberikan bobot yang lebih besar, sedangkan yang tidak dominan diberi bobot yang lebih rendah. Jumlah total setiap baris dari matriks partisi tersebut sama dengan 1.

Matriks partisi yang sudah dibuat kemudian dihubungkan dengan sampel (training site) yang telah ditentukan sebelumnya. Training site yang telah memiliki nilai keanggotaan baru, kemudian dilakukan signature development lewat fuzsig menjadi daerah contoh baru menjadi training area fuzzy yang akan digunakan dalam eksekusi klasifikasi atau proses defuzzifikasi.

\section{c. Proses eksekusi klasifikasi menggunakan algoritma maximum}

\section{likelihood}

Dari citra hasil proses klasifikasi digital yang masih berbasis fuzzy dilakukan proses defuzzifikasi dengan maksud untuk mempertegas (mempertajam) batas-batas antar kelasnya.

Pada proses eksekusi ini training area fuzzy digunakan sebagai input, yang pembobotannya secara otomatis dihitung oleh komputer apabila kita memilih option use equal prior probabilities for each signature. Bobot yang diberikan pada penelitian ini yaitu o,o71, nilai bobot tersebut diberikan sama nilainya untuk setiap kelas penggunaan lahan. Untuk melihat seberapa ef isienkah proses ini maka diperlukan pencatatan waktu, dari hasil pencatatan waktu untuk proses eksekusi menggunakan algoritma maximum likelihood sekitar 10 detik. Software yang digunakan pada pemrosesan ini yaitu menggunakan software Idrisi Selva. Citra hasil eksekusi klasif ikasi menggunakan algoritma maximum likelihood dapat dilihat pada gambar 9. Sedangkan Peta Penggunaan Lahan hasil defuzzifikasi menggunakan algoritma maximum likelihood, yang telah diolah legenda dan proses layout-nya pada software ArcGIS dapat dilihat pada gambar 10.

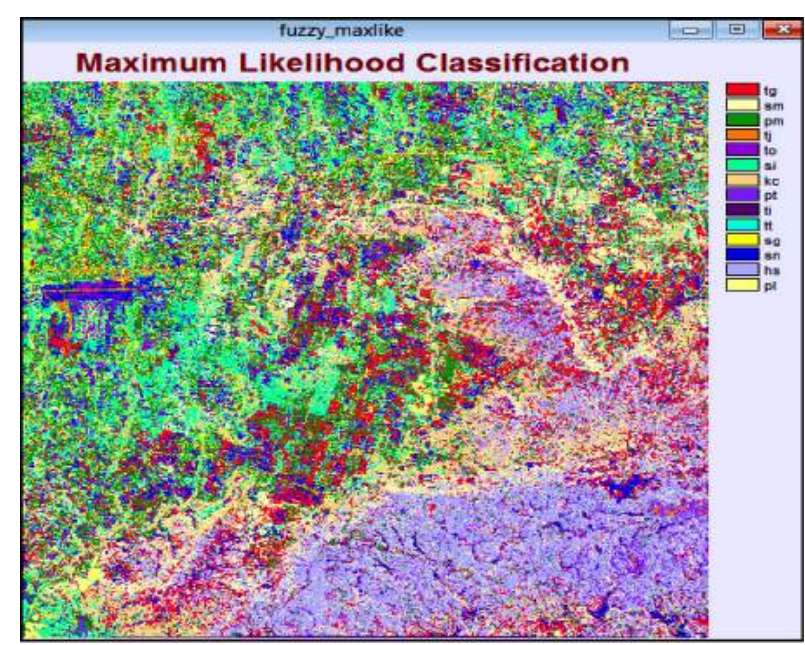

Gambar 9. Citra hasil eksekusi klasifikasi menggunakan algoritma maximum likelihood pada i4 kelas penggunaan lahan 

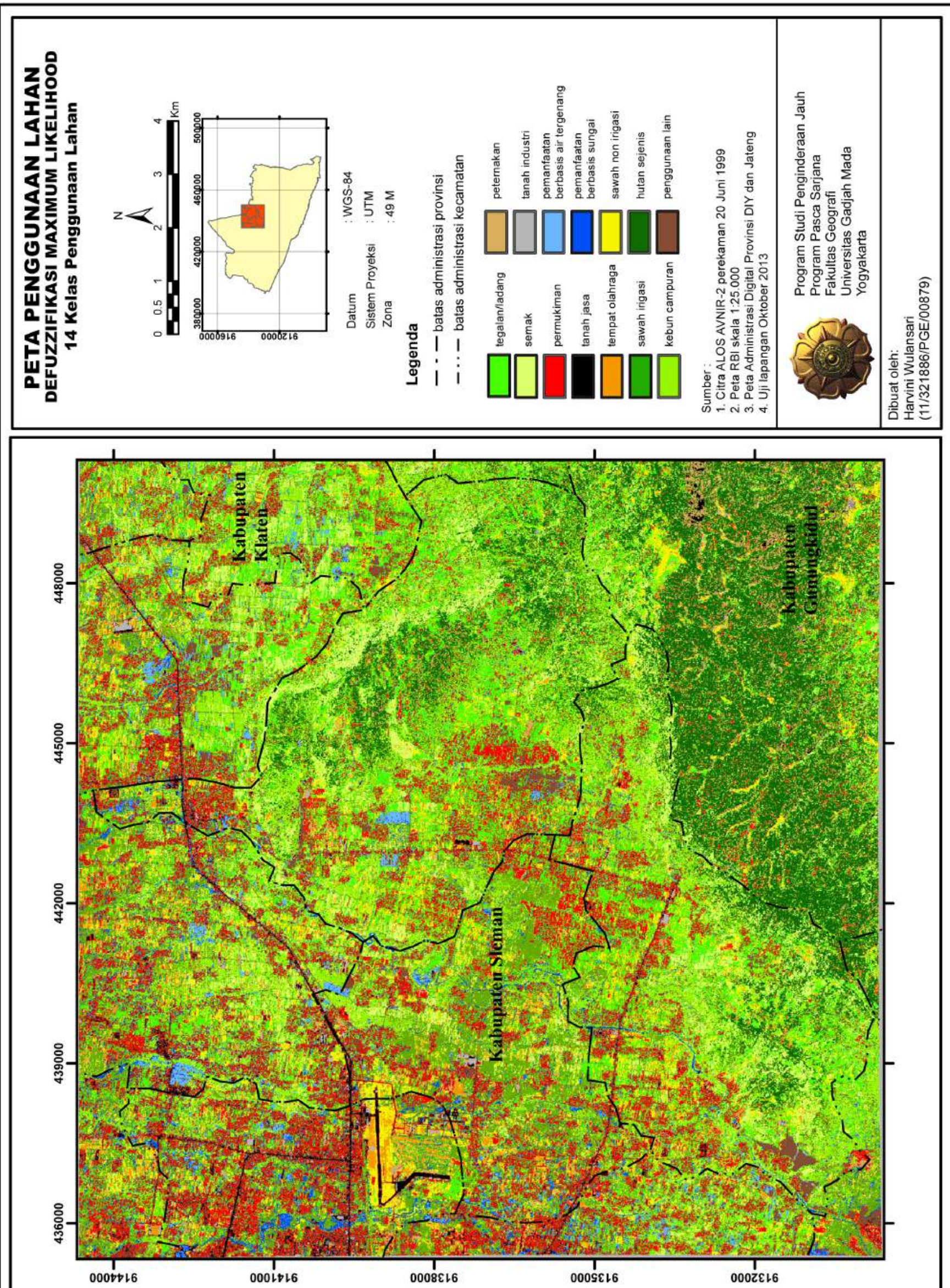


\section{Tahap Pasca Lapangan (Uji Akurasi)}

Uji akurasi hasil klasifikasi dilakukan untuk menguji tingkat akurasi peta penggunaan yang dihasilkan dari proses klasifikasi digital dengan sampel uji dari hasil kegiatan lapangan. Antara sampel yang digunakan sebagai training area dengan sampel yang digunakan untuk uji akurasi bukan sampel yang sama tetapi sampel uji akurasi diambil di tempat yang berbeda, hal ini agar lebih diterima keakuratannya.

Metode yang digunakan untuk menghitung akurasi klasifikasi dengan menggunakan matriks kesalahan atau confusion matrix/error matrix dapat dilihat pada tabel 8, untuk selanjutnya menurut Jensen (2005) dapat dilakukan perhitungan producer's accuracy, user's accuracy, overall accuracy dan nilai indeks kappa.

Tabel 8 Matriks kesalahan (error matrix)

\begin{tabular}{|c|c|c|c|c|c|c|c|c|c|}
\hline & \multicolumn{7}{|c|}{ Data acuan } & \multirow[b]{2}{*}{ Total baris } \\
\hline & & PLI & PL II & PL III & PL IV & PLV & PL VI & PL VII & \\
\hline \multirow{7}{*}{$\begin{array}{c}\text { Hasil } \\
\text { Klasifikasi }\end{array}$} & PLI & A & $a$ & $\mathrm{~b}$ & c & D & e & $\mathrm{f}$ & $\Sigma$ baris 1 \\
\hline & PL II & $\mathrm{g}$ & B & $\mathrm{h}$ & $\mathrm{i}$ & J & $\mathrm{k}$ & 1 & $\Sigma$ baris 2 \\
\hline & PL III & $\mathrm{m}$ & $\mathrm{n}$ & C & o & $P$ & $q$ & $\mathrm{r}$ & $\Sigma$ baris 3 \\
\hline & PLIV & $\mathrm{s}$ & $\mathrm{t}$ & $\mathrm{u}$ & D & $\mathrm{v}$ & $\mathrm{w}$ & $\mathrm{x}$ & $\Sigma$ baris 4 \\
\hline & PLV & $\mathrm{y}$ & $\mathrm{z}$ & $a^{\prime}$ & $\mathrm{b}^{\prime}$ & E & $c^{\prime}$ & $d^{\prime}$ & $\Sigma$ baris 5 \\
\hline & PL VI & $\mathrm{e}^{\prime}$ & $f^{\prime}$ & $\mathrm{g}^{\prime}$ & $\mathrm{h}^{\prime}$ & $i^{\prime}$ & $F$ & $j^{\prime}$ & $\Sigma$ baris 6 \\
\hline & PL VII & $\mathrm{k}^{\prime}$ & $I^{\prime}$ & $\mathrm{m}^{\prime}$ & $\mathrm{n}^{\prime}$ & $\mathrm{o}^{\prime}$ & $\mathrm{p}^{\prime}$ & G & $\Sigma$ baris 7 \\
\hline $\begin{array}{l}\text { Total } \\
\text { kolom }\end{array}$ & & $\begin{array}{c}\Sigma \\
\text { kolom } \\
1\end{array}$ & $\begin{array}{c}\Sigma \\
\text { kolom } \\
2\end{array}$ & $\begin{array}{c}\Sigma \\
\text { kolom } \\
3\end{array}$ & $\begin{array}{c}\Sigma \\
\text { kolom } \\
4\end{array}$ & $\begin{array}{c}\Sigma \\
\text { kolom } \\
5\end{array}$ & $\begin{array}{c}\Sigma \\
\text { kolom } \\
6\end{array}$ & $\begin{array}{c}\Sigma \\
\text { kolom } \\
7\end{array}$ & $\begin{array}{c}\Sigma \text { total } \\
\text { kolom/baris }\end{array}$ \\
\hline
\end{tabular}

Keterangan:

$A, B, C, \ldots \ldots . . ., G=$ jumlah piksel benar dari hasil interpretasi dan cek lapangan.

a,b,c...,a',b',...,p' = jumlah piksel dalam satu kelas hasil pengujian lapangan

Producer's accuracy merupakan akurasi yang dilihat dari sisi penghasil peta, sedangkan user's accuracy merupakan akurasi yang dilihat dari sisi pengguna petanya. Pada tabel perhitungan juga terdapat istilah omisi kesalahan yaitu kesalahan karena adanya penghilangan, sebaliknya komisi kesalahan yaitu kesalahan karena adanya penambahan.

Uji akurasi dihitung dengan menggunakan rumus producer's accuracy dan user's accuracy yang dapat dilihat pada tabel 8. Selain itu juga akan dilakukan perhitungan overall accuracy dengan rumus:
Overail accunacy $=\mathrm{A}+\mathrm{B}+\mathrm{C}+\mathrm{D}+\mathrm{E}+\mathrm{F}+\mathrm{G}$

I total knlam

Dan perhitungan nilai Indeks Kappa :

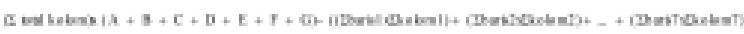

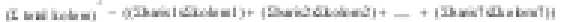

Tabel 8. Perhitungan akurasi penghasil dan pengguna berdasarkan matriks kesalahan

\begin{tabular}{|c|c|c|c|c|}
\hline Kelas & $\begin{array}{l}\text { Producer's } \\
\text { accuracy }\end{array}$ & & $\begin{array}{l}\text { User's } \\
\text { accuracy }\end{array}$ & \\
\hline & Akurasi & $\begin{array}{l}\text { Omisi } \\
\text { kesalahan }\end{array}$ & Akurasi & $\begin{array}{l}\text { Komisi } \\
\text { kesalahan }\end{array}$ \\
\hline PLI & 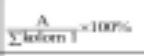 & 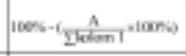 & I A A & 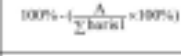 \\
\hline PL. II & 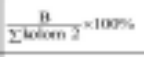 & 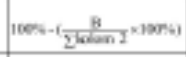 & $\frac{B}{2 \tan 25} \times 100 x$ & 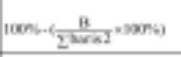 \\
\hline PL III & 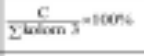 & 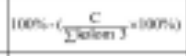 & $\frac{C}{2^{\operatorname{tanis} x}}=100$ s: & $100 \pi \cdot \frac{c}{\sum^{2} \sin x^{2}}=1000$ \\
\hline PL. IV & 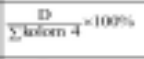 & 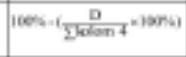 & 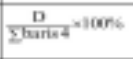 & 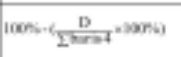 \\
\hline PL. V & $\frac{E}{\sum \operatorname{lnatan} 3}$ & 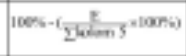 & $\frac{E}{2 \text { kariss }} \times 1006$ & 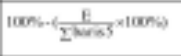 \\
\hline PL VI & 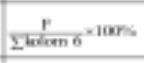 & $100 \pi-\left(\frac{f}{2 \operatorname{atan} t}=190 \pi\right)$ & 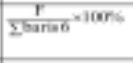 & 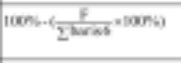 \\
\hline PL VII & 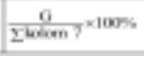 & 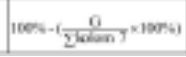 & 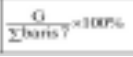 & 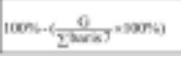 \\
\hline
\end{tabular}

a. Hasil perhitungan producer's accuracy dan user's accuracy 14 kelas penggunaan lahan

Hasil perhitungan producer's accuracy dan user's accuracy 14 kelas penggunaan lahan dapat dilihat pada tabel 9.

Tabel 9. Perhitungan akurasi penghasil dan pengguna untuk 14 kelas penggunaan lahan (defuzzifikasi menggunakan maximum likelihood)

\begin{tabular}{|c|c|c|c|c|}
\hline \multirow{2}{*}{ Kelas } & \multicolumn{2}{|c|}{ Producer's accuracy } & \multicolumn{2}{c|}{ User's accuracy } \\
\cline { 2 - 5 } & $\begin{array}{c}\text { Akurasi } \\
(\%)\end{array}$ & $\begin{array}{c}\text { Omisi } \\
\text { kesalahan }(\%)\end{array}$ & $\begin{array}{c}\text { Akurasi } \\
(\%)\end{array}$ & $\begin{array}{c}\text { Komisi } \\
\text { kesalahan }(\%)\end{array}$ \\
\hline $\mathrm{Tg}$ & 38,80 & 61,20 & 27,73 & 72,27 \\
\hline $\mathrm{Sm}$ & 75,52 & 24,48 & 65,47 & 34,53 \\
\hline $\mathrm{Pm}$ & 49,77 & 50,23 & 56,65 & 43,35 \\
\hline $\mathrm{Tj}$ & 42,76 & 57,24 & 70,45 & 29,55 \\
\hline $\mathrm{To}$ & 90,16 & 9,84 & 94,83 & 5,17 \\
\hline $\mathrm{Si}$ & 17,73 & 82,27 & 15,34 & 84,66 \\
\hline $\mathrm{Kc}$ & 29,52 & 70,48 & 24,14 & 75,86 \\
\hline $\mathrm{Pt}$ & 4,46 & 95,54 & 4,00 & 96,00 \\
\hline $\mathrm{Ti}$ & 57,24 & 42,76 & 78,30 & 21,70 \\
\hline $\mathrm{At}$ & 58,19 & 41,81 & 87,29 & 12,71 \\
\hline $\mathrm{Sg}$ & 73,54 & 26,46 & 80,77 & 19,23 \\
\hline $\mathrm{Sn}$ & 71,16 & 28,84 & 64,02 & 35,98 \\
\hline $\mathrm{Hs}$ & 79,55 & 20,45 & 75,92 & 24,08 \\
\hline $\mathrm{Pl}$ & 33,33 & 66,67 & 30,95 & 69,05 \\
\hline
\end{tabular}

Sumber : Pengolahan penelitian, 2013 
Dari tabel 9 dapat dilihat bahwa akurasi tertinggi untuk 14 kelas penggunaan lahan pada proses defuzzifikasi menggunakan maximum likelihood tingkat akurasi penghasil atau producer's accuracy sebesar 90,16\% yaitu kelas penggunaan lahan tempat olahraga (to) dengan omisi kesalahan sebesar 9,84\% sedangkan akurasi terendah sebesar 4,46\% yaitu kelas penggunaan lahan peternakan dengan omisi kesalahan sebesar 95,54\%, Pada tingkat akurasi pengguna atau user's accuracy akurasi tertinggi sebesar 94,83\% yaitu kelas penggunaan lahan tempat olahraga dengan komisi kesalahan sebesar 5,17\%, sedangkan akurasi terendah sebesar $4 \%$ yaitu kelas penggunaan lahan peternakan dengan komisi kesalahan sebesar 96\%.

\section{a. Hasil Perhitungan Overall Accuracy dan Indeks Kappa}

Hasil perhitungan overall accuracy dan indeks kappa untuk 14 kelas penggunaan lahan proses defuzzifikasi maximum likelihood dapat dilihat pada tabel 10.

Tabel 10. Perhitungan overall accuracy dan indeks kappa dengan proses defuzzifikasi menggunakan algoritma maximum likelihood

\begin{tabular}{|l|c|c|}
\hline \multicolumn{1}{|c|}{ Jumlah kelas } & overall accuracy & indeks kappa \\
\hline 14 kelas & $57 \%$ & 0,53 \\
\hline
\end{tabular}

Sumber: Pengolahan penelitian, 2013

\section{Penutup}

Proses penelitian berhasil dengan baik, menghasilkan peta yang informatif dengan klasifikasi yang bervariasi, walaupun dari sudut pandang ketelitian menghasilkan overall accuracy dan indeks kappa yang kurang baik atau kurang layak apabila menggunakan acuan akurasi yang dianggap layak untuk penggunaan citra satelit 80\% - 85\% (Sutanto,2013). Hasil perhitungan overall accuracy untuk 14 kelas penggunaan lahan proses defuzzifikasi maximum likelihood yaitu $57 \%$ sedangkan indeks kappa 0,53 namun demikian hasilnya masih dapat diterima. Sedangkan hasil pencatatan waktu untuk proses eksekusi menggunakan algoritma maximum likelihood sekitar 10 detik.

Hasil akurasi yang kurang baik dalam penelitian ini bisa disebabkan oleh beberapa kemungkinan diantaranya yaitu dalam interpretasi sampel di citra dengan kondisi sebenarnya di lapangan ada perbedaan disebabkan karena citra yang digunakan merupakan hasil perekaman tahun 2009 sedangkan penelitian dilakukan tahun 2013 tentu saja ada kemungkinan kondisi lapangan sudah berubah meskipun wawancara yang dilakukan dengan penduduk sekitar sudah dilakukan tetapi belum tentu informasi tersebut akurat karena rentang waktu yang cukup lama.

Selain itu kemungkinan dalam hal penentuan derajat keanggotaan himpunan fuzzy dibutuhkan analisisyang baik oleh orang yang benar benarahlinya, karena dalam penelitian ini peneliti masih pemula dalam melakukan analisis/bukan ahlinya maka bisa saja terjadi kesalahan dalam pemberian bobot-bobot (membership grade) keanggotaan.

\section{Daftar Pustaka}

Danoedoro, P., 2012, Pengantar Penginderaan Jauh Digital, Penerbit Andi, Yogyakarta.

Denaswidhi, E., 2008, Pendekatan Logika Samar (Fuzzy Logic) untuk Pemetaan Penggunaan Lahan Sebagian Kota Semarang dari Citra Landsat ETM+ Multitemporal, Skripsi, Fakultas Geografi Universitas Gadjah Mada Yogyakarta.

Direktorat Pemetaan Tematik, 2012, Norma, Standar, Prosedur dan Kriteria, Deputi Bidang Survei, Pengukuran dan Pemetaan, BPN RI.

Jensen, J.R., 2005, Introductory Digital Image Processing : A Remote Sensing Perspective, Third Edition, Pearson Education, Inc., United States of America.

Kusumadewi, S., dan Purnomo, H., 2010, Aplikasi Logika Fuzzy Untuk Pendukung Keputusan, Edisi 2, Penerbit Graha Ilmu, Yogyakarta. 
Lillesand, T.M., Kiefer, R.W., and Chipman, J., 2008, Remote Sensing and Image Interpretation, Sixth Edition, John Wiley and Sons, Inc.

Novamizanti et.al., 2010, Optimasi Logika Fuzzy Menggunakan Algoritma Genetika Pada Identifikasi Pola Tanda Tangan, Jurnal, Konferensi Nasional Sistem dan Informatika Bali, hal: 153.

Schowengerdt, R.A., 1983, Techniques for Image Processing and Classification in Remote Sensing, Academic Press, London.
Sutanto, 2010, Remote Sensing Research: A User's Perspective, Indonesian Journal of Geography, Faculty of Geography Gadjah Mada Univ. and The Indonesian Geographers Association, hal: 131.

Sutanto, 2013, Metode Penelitian Penginderaan Jauh, Penerbit Ombak, Yogyakarta.

http://www.ga.gov.au/webtemp/image cache / GA10286.pdfy', diakses tanggal 21 September 2013 